\title{
Influence of Temperature on the Development of Peach Fruit in a Subtropical Climate Region
}

\author{
Filipe Souza ${ }^{1,2, *}$, Eduardo Alves ${ }^{3}$, Rafael Pio ${ }^{1}$, Elisa Castro ${ }^{3}$, Gregory Reighard ${ }^{4}$, \\ Ana Izabella Freire ${ }^{5}$, Newton Alex Mayer ${ }^{6}\left(\mathbb{D}\right.$ and Róberson Pimentel ${ }^{7}$ \\ 1 Departamento de Agricultura, Universidade Federal de Lavras (UFLA), Lavras-MG 37200-000, Brazil; \\ rafaelpio@dag.ufla.br \\ 2 Departamento de Agronomia, Centro Universitário Tocantinense Presidente Antônio Carlos (UNITPAC), \\ Araguaína-TO 77816-540, Brazil \\ 3 Departamento de Fitopatologia, Universidade Federal de Lavras, Lavras-MG 37200-000, Brazil; \\ ealves@ufla.br (E.A.); elisa.castro@prp.ufla.br (E.C.) \\ 4 Horticulture Program Team, Plant and Environmental Sciences Department, Clemson University, Clemson, \\ SC 29634, USA; grghrd@clemson.edu \\ 5 Departmento de Fitotecnia, Universidade Federal de Viçosa/UFV, Viçosa-MG 36570-900, Brazil; \\ ana.izabella@ufv.br \\ 6 Embrapa Clima Temperado, BR 392, km 78, Caixa Postal 403, Pelotas 96010-971, Brazil; \\ alex.mayer@embrapa.br \\ 7 Departamento de Medicina Veterinária, Universidade Federal Fluminense (UFF), Niterói-RJ 24230-340, \\ Brazil; robersonmp@id.uff.br \\ * Correspondence: filipesouza@itpac.br; Tel.: +55-63-99222-4011
}

Received: 31 October 2018; Accepted: 17 December 2018; Published: 7 January 2019

\begin{abstract}
Understanding the growing process and fruit size differences among peach cultivars is extremely important in the technological domain of the crop and can provide information to improve the proper crop management (thinning and harvesting seasons) and the crop breeding of fruits with a larger caliber. However, this information is still incipient in subtropical regions and requires further research, especially in Brazil. The aim of this study was to determine the influence of temperature on the growing of four peach cultivars (Tropical, Aurora-2, Ouro Mel-4, and Biuti) under subtropical conditions of field cultivation. Fruit development was determined every two weeks throughout the cycle with 30 fruits from previously identified branches from six different plants of each cultivar. Regarding the thermal accumulation in growing degree-days (GDD), the cultivar 'Tropical' showed the lowest agronomic fruit properties (size and mass) and required a lower GDD accumulation during the development stages of the fruits, whereas the cultivar 'Biuti' showed higher thermal requirements and higher agronomic properties. The number of cells had greater influence on the final fruit size than the cell area.
\end{abstract}

Keywords: cell area; mesocarp; number of cells; Prunus persica L.; scanning electron microscopy

\section{Introduction}

Peach (Prunus persica (L.) Batsch) is the third most economically important fruit crop in temperate zones and are also one of the model species of Rosaceae [1]. Brazil is the 14th largest world producer of peaches. In 2013, 217,706 tones were produced in an area of 18,091 hectares, corresponding to a productivity of $12.03 \mathrm{th}^{-1}$ [2].

Large fruit size is an essential characteristic for commercial peach cultivars. Fruit size is a function of genotype and environment [3]. Although the major factor affecting fruit size is genotype, within 
the genetic limitations of a particular cultivar, fruit size can be increased by early fruit thinning [4], girdling [5], and the application of growth regulators [5,6].

Fruit size has been regarded to be a function of cell division in the early stages of development and of cell enlargement in the final stages of fruit growth [7]. Differences in peach fruit size among trees of the same cultivar have been shown to be chiefly due to differences in cell count, with cell size having a minor effect [8]. However, the differences in fruit size among cultivars are not well clarified or understood. Fruit size is apparently determined by the number and the size of flesh cells [9]. Understanding the fruit size differences among cultivars should lead to more effective fruit thinning and adequate crop loading and to the efficient breeding of big peach cultivars [10].

Peach and nectarine fruit exhibit a double-sigmoid growth pattern consisting of four distinct stages in which development is expressed as fruit diameter $[9,11,12]$. Two stages of faster growth (S1 and S3) alternate with two stages of slower increases in fruit diameter (S2 and S4) [13]. The length of each developmental stage is cultivar-dependent, with early-ripening cultivars having a significantly shorter cell-division and pit-hardening period than late-ripening cultivars [10].

There are few studies on the growth curve of peach fruits in different regions of Brazil in the literature [14-16]. Researchers in other countries observed that difference in fruit size between genotypes has a strong genetic influence and is broadly explained by differences in the total number of cells in the mesocarp $[3,10,14]$. Yamaguchi $[10]$ reported a significant correlation between cell length and fruit size in a large number of peach cultivars, although cell number was the most stable indicator of size. These results suggest that cell size may also be an important genetic component contributing to fruit size.

DeJong and Goudriaan [17] have shown that the accumulation of degree-days has been an efficient growing time measurement of drupes. Most of the studies on fruit development have been made considering the diameter and the fresh mass of fruits [15]. Thus, by gathering these parameters we expect to verify the influence of temperature on fruit development.

Therefore, the aim of this study was to evaluate the influence of temperatures on the fruit development of four peach genotypes in subtropical regions.

\section{Materials and Methods}

\subsection{Climatic Characterization and Plant Material}

The experiment was performed at the Federal University of Lavras (UFLA), Lavras, Minas Gerais, Brazil, during the year 2016. According to Souza [18], the municipality is situated at $21^{\circ} 14^{\prime} 06^{\prime \prime} \mathrm{S}$ and $45^{\circ} 00^{\prime} 00^{\prime \prime} \mathrm{W}, 918 \mathrm{~m}$ altitude, and classified as a Cwb climate (subtropical mesothermic climate).

Four genotypes that are widely cultivated in the subtropical regions of Brazil were used: 'Aurora-2', 'Tropical', 'Ouro Mel-4' and 'Biuti'. The plants were aged six years at the beginning of the study, grafted on the seedlings of 'Okinawa' rootstock with a spacing between plants of $5 \mathrm{~m} \times 1.5 \mathrm{~m}$, and using a "V" system. Pruning and flower induction were performed on 25 June of each year when the plant buds were still dormant. Hydrogen cyanamide (Dormex ${ }^{\circledR}$ ) was used at a concentration of $0.25 \%$ and was applied in the second fortnight of June of each year, as recommended by Souza [19].

\subsection{Flowering Phenology}

The phenological study was carried out in six plants per cultivar and monitored every day right after the dormancy period from the beginning of flowering (BF) until the end of harvest (EH) in the plant as a whole. For the fruit development analysis, the phenological stages were related to the GDD during the productive cycle (Table 1): (I) beginning of flowering (BF), corresponding to $5 \%$ of open flowers; (II) full bloom (FB), when $50 \%$ of flowers are opened; (III) end of flowering (EF), when over $75 \%$ of flowers are opened and the petals of flowers begin to fall; (IV) end of harvest (EH), referring to the period of the final harvest of fruits, where they are in the senescence stage; and productive cycle (PC), which is the chronological time in days from FB to EH, according to Souza [20]. 
Table 1. Gathering of phenological stages: beginning of flowering (BF), full bloom (FB), end of flowering $(\mathrm{EF})$, duration of flowering (DF), expressed in days, end of harvest (EH), and the productive cycle (PC), expressed in days, from peach cultivars Aurora-2, Ouro Mel-2, Tropical and Biuti in 2016. Federal University of Lavras, Lavras, MG, Brazil, 2016.

\begin{tabular}{ccccccc}
\hline Cultivar & BF & FB & EF & DF & EH & PC \\
\hline Aurora-2 & $05 / 07$ & $20 / 07$ & $01 / 08$ & 17 & $10 / 10$ & 98 \\
Ouro Mel-4 & $11 / 07$ & $20 / 07$ & $09 / 08$ & 29 & $07 / 11$ & 120 \\
Tropical & $05 / 07$ & $22 / 07$ & $03 / 08$ & 29 & $07 / 11$ & 126 \\
Biuti & $20 / 07$ & $01 / 08$ & $23 / 08$ & 34 & $06 / 12$ & 140 \\
\hline
\end{tabular}

\subsection{Temperature-GDD Relation}

The relationship between temperature and fruit growth was measured based on the GDD accumulation instead of standard time intervals. The ambient temperatures were monitored by the main weather station of Lavras, located $0.5 \mathrm{~km}$ from the study site. The GDDs were calculated from the minimum and maximum daily temperatures, using the method by McMaster and Wilhelm [21] with lower and upper temperature thresholds at 7 and $35^{\circ} \mathrm{C}$. The results are described in Table 2.

Table 2. Sampling periods (SP), accumulation of growing degree-days (GDD) from the date of full bloom (FB) to fruit senescence, average cell area (CA) in $\mu \mathrm{m}^{2}$ and average cell number of mesocarp (CN) for the cultivars Aurora-2, Ouro Mel-4, Tropical and Biuti, in Lavras, MG, Brazil.

\begin{tabular}{|c|c|c|c|c|c|c|c|c|c|c|}
\hline \multirow{2}{*}{ SP } & \multicolumn{5}{|c|}{ Tropical } & \multicolumn{5}{|c|}{ Biuti } \\
\hline & GDD & CA & SD & $\mathrm{CN}$ & SD & GDD & CA & SD & $\mathrm{CN}$ & SD \\
\hline 04/08 & 183.95 & \multicolumn{2}{|c|}{$0.71 \pm 0.21$} & \multicolumn{2}{|c|}{$95.50 \pm 2.62$} & - & - & - & - & - \\
\hline $19 / 08$ & 378.50 & \multicolumn{2}{|c|}{$0.94 \pm 0.18$} & \multicolumn{2}{|c|}{$105.47 \pm 0.53$} & 240.00 & \multicolumn{2}{|c|}{$0.94 \pm 0.49$} & \multicolumn{2}{|c|}{$61.17 \pm 21.25$} \\
\hline 02/09 & 549.85 & \multicolumn{2}{|c|}{$3.11 \pm 0.80$} & \multicolumn{2}{|c|}{$119.28 \pm 1.06$} & 411.35 & \multicolumn{2}{|c|}{$2.24 \pm 0.16$} & \multicolumn{2}{|c|}{$93.55 \pm 4.43$} \\
\hline $16 / 09$ & 763.40 & \multicolumn{2}{|c|}{$5.34 \pm 0.57$} & \multicolumn{2}{|c|}{$122.04 \pm 5.68$} & 624.90 & \multicolumn{2}{|c|}{$2.86 \pm 0.09$} & \multicolumn{2}{|c|}{$144.99 \pm 5.9$} \\
\hline $30 / 09$ & 973.15 & \multicolumn{2}{|c|}{$7.29 \pm 0.82$} & \multicolumn{2}{|c|}{$125.61 \pm 6.73$} & 834.65 & \multicolumn{2}{|c|}{$3.09 \pm 0.28$} & \multicolumn{2}{|c|}{$146.42 \pm 6.1$} \\
\hline $10 / 10$ & 1106.90 & \multicolumn{2}{|c|}{$6.81 \pm 4.57$} & \multicolumn{2}{|c|}{$92.11 \pm 78.85$} & 1029.80 & \multicolumn{2}{|c|}{$4.1 \pm 0.26$} & \multicolumn{2}{|c|}{$150.78 \pm 6.5$} \\
\hline $14 / 10$ & - & - & - & - & - & 1258.15 & \multicolumn{2}{|c|}{$5.2 \pm 0.17$} & \multicolumn{2}{|c|}{$164.49 \pm 4.3$} \\
\hline $27 / 10$ & - & - & - & - & - & 1530.80 & \multicolumn{2}{|c|}{$8.0 \pm 0.23$} & \multicolumn{2}{|c|}{$202.96 \pm 18.07$} \\
\hline \multirow{4}{*}{$\begin{array}{c}06 / 12 \\
\text { Days }\end{array}$} & - & - & - & - & - & 1845.21 & \multirow{2}{*}{\multicolumn{2}{|c|}{$\begin{array}{c}9.1 \pm 1.11 \\
109\end{array}$}} & \multirow{2}{*}{\multicolumn{2}{|c|}{$184.18 \pm 15.81$}} \\
\hline & & & 67 & & & & & & & \\
\hline & & & ro $\mathbf{M}$ & & & & & arora & & \\
\hline & GDD & CA & SD & $\mathrm{CN}$ & SD & GDD & CA & SD & $\mathrm{CN}$ & SD \\
\hline 04/08 & 183.95 & 0.4 & .04 & 126. & 5.4 & 04/08 & 0.69 & & 81.8 & 9.61 \\
\hline $19 / 08$ & 378.50 & 1.8 & 10 & 130.7 & 12.85 & $19 / 08$ & 2.40 & 19 & 123. & 9.09 \\
\hline 02/09 & 549.85 & 2.2 & .11 & 133. & 4.12 & $02 / 09$ & 2.59 & & 150. & 7.35 \\
\hline $16 / 09$ & 763.40 & 2.9 & 12 & 159. & 3.97 & $16 / 09$ & 5.18 & & 140.8 & 16.81 \\
\hline $30 / 09$ & 973.15 & 3.8 & 13 & 246.7 & 31.33 & $30 / 09$ & 6.49 & & 144.5 & 11.40 \\
\hline $14 / 10$ & 1168.30 & 5.6 & 84 & 229.2 & 15.46 & $14 / 10$ & 8.56 & & 170.3 & 19.84 \\
\hline $27 / 10$ & 1396.65 & 5.8 & 23 & 237. & 7.55 & $27 / 10$ & 14.1 & .18 & 165.1 & 13.47 \\
\hline $07 / 11$ & 1547.35 & 7.7 & .22 & 218 & 8.14 & $07 / 11$ & 15.1 & .64 & 183. & 9.22 \\
\hline Days & & & 120 & & & & & & & \\
\hline
\end{tabular}

SD: standard deviation.

\subsection{Sampling}

In each sampling period (Table 3), thirty fruits with similar diameters (five fruits per plant) that had initiated from the full bloom (FB) of each cultivar were collected randomly from previously marked branches located in the median plant region ( $1.5 \mathrm{~m}$ above the ground), as performed by Reighard et al. [22] The mass (g), the transverse and longitudinal meridional section of fruits, and the exocarp (mm) were evaluated using a STARRETT ${ }^{\circledR}$ digital caliper (LS Starrett Co., Athol, MA, USA). These measurements provided the cross-sectional area of the fruit and the cross-sectional area of the endocarp. 


\subsection{Microscopy Analysis}

After sampling, the fruits were cut using a scalpel and sampled with standardized dimensions in the pericarp region, which extends from the exocarp to the mesocarp region. They were then immersed in a fixative solution (modified Karnovsky), $\mathrm{pH} 7.2$ for at least $24 \mathrm{~h}$, washed in cacodylate buffer (three times every $10 \mathrm{~min}$ ) to remove the glutaraldehyde residues, and post-fixed in $1 \%$ osmium tetroxide in water for $1 \mathrm{~h}$ (by mixing equal volumes of $2 \%$ osmium tetroxide in $0.1 \mathrm{M}$ cacodylate buffer). After this period, the samples were washed three times in distilled water and then dehydrated in acetone gradient $(25 \%, 50 \%, 75 \%, 90 \%$ and $100 \%$ three times). Subsequently, the material drying was concluded using critical point apparatus, then assembled in stubs and covered with gold [23]. The seed images were made in a scanning electron microscope Leo Electron (Zeiss, Cambridge, UK) at the Laboratory of Electron Microscopy and Ultra-Structural Analysis, Federal University of Lavras.

Areas of the epidermis and locules were excluded from the total fruit cross-section area to determine the mesocarp area. Images of sectioned fruit were printed to determine the cell number $(\mathrm{CN})$ and cell area (CA). The mesocarp region was divided into three zones: outer mesocarp, middle mesocarp, and inner mesocarp [24]. A grid of known area was placed over each of the three zones and the cells that were at least $50 \%$ within the grid were counted. The grid area was divided by the number of cells within it to determine the cell area. The average cell area (CA) is presented. Cell number (CN) was determined by dividing the mesocarp area by the average cell area. Image analysis was performed using Infinity Analyze software 6.4.1, avoiding vascularized and deformed cell regions (Figure 1).
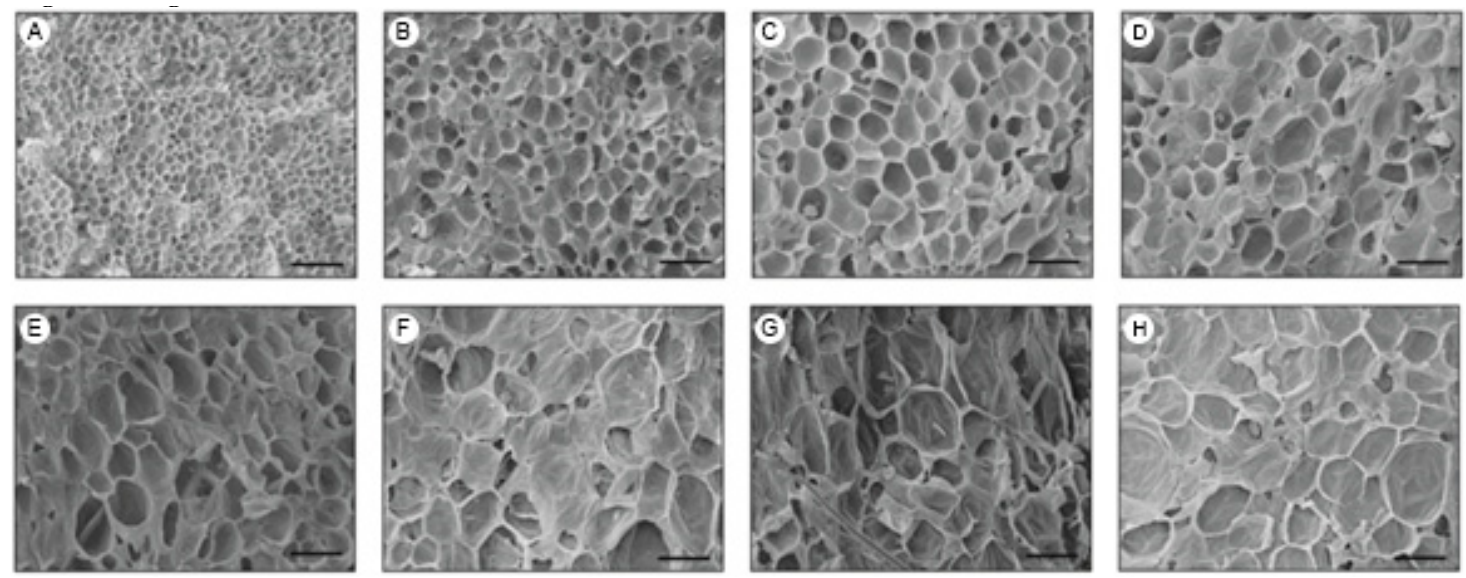

Figure 1. Microphotographs of the scanning electron microscope of the fruit cross-section during the mesocarp development of the peach cultivar Ouro Mel-4: (A) 4 August (183.95 GDD), (B) 19 August (378.50 GDD); (C) 2 September (549.85 GDD), (D) 16 September (763.40 GDD), (E) 30 September (973.15 GDD), (F) 14 October (1168.30 GDD), (G) 27 October (1396.65 GDD) of physiological maturity point and (H) 7 November (1547.35 GDD) senescence stage. Bar represents $10 \mu \mathrm{m}$. Federal University, Lavras, MG, Brazil, 2016.

\subsection{Statistical Analysis}

The statistical design adopted in the experiment was split-plot in time, where the collection times referred to the plots and the cultivars constituted the subplots. A total of 30 treatments were used and each treatment consisted of four replicates.

The data normality was evaluated using the Shapiro-Wilk test at $5 \%$ significance with subsequent statistical assumptions. The analysis of variance was performed and the mass, fruit diameter, and endocarp data were obtained for each sample and analyzed through descriptive statistics, and the results were expressed by means followed by the respective standard deviations. Moreover, the non-linear logistic model (Equation (4)) was fitted for the cell number (CN) and cell area (CA) of the cultivars [25]. 
Equation (4) presents the logistic model:

$$
\hat{y}=\frac{\beta 1}{1+\beta 2 \times 10^{(-\beta 3 x)}}+\varepsilon i
$$

where $\beta 1$ is the parameter representing the asymptotic cell area (CA) or cell number $(C N) ; \beta 2$ is a location parameter, without biological interpretation; $\beta 3$ is the parameter that represents the growth rate, or growth speed; Yi represents the observation in the dependent variable (or response variable); $\mathrm{X}$ i represents the independent variable (or predictor variable); and $\varepsilon$ i represents the random error, assuming $\varepsilon i \sim \mathrm{N}(0, \sigma 2)$.

\section{Results and Discussion}

\subsection{Climate Description}

According to the climate data (Figure 2) collected between July and December 2016, the average maximum temperature was $27.5^{\circ} \mathrm{C}$, the average minimum temperature was $14.7^{\circ} \mathrm{C}$, and the mean temperature was $20.2^{\circ} \mathrm{C}$ (Figure 1). The temperature during the phenological study ranged between $34.6^{\circ} \mathrm{C}$ (19 October) and $3.7^{\circ} \mathrm{C}$ (18 July). Extreme GDDs were also recorded (20 GDD on 19 October and $6.5 \mathrm{GDD}$ on $18 \mathrm{July})$. The month of August was characterized by the lowest mean temperatures $\left(17.4^{\circ} \mathrm{C}\right)$ and lowest average GDD accumulation (11.3), whereas December showed the highest mean temperatures $\left(22.1^{\circ} \mathrm{C}\right)$ and the highest average GDD accumulation (15.9).

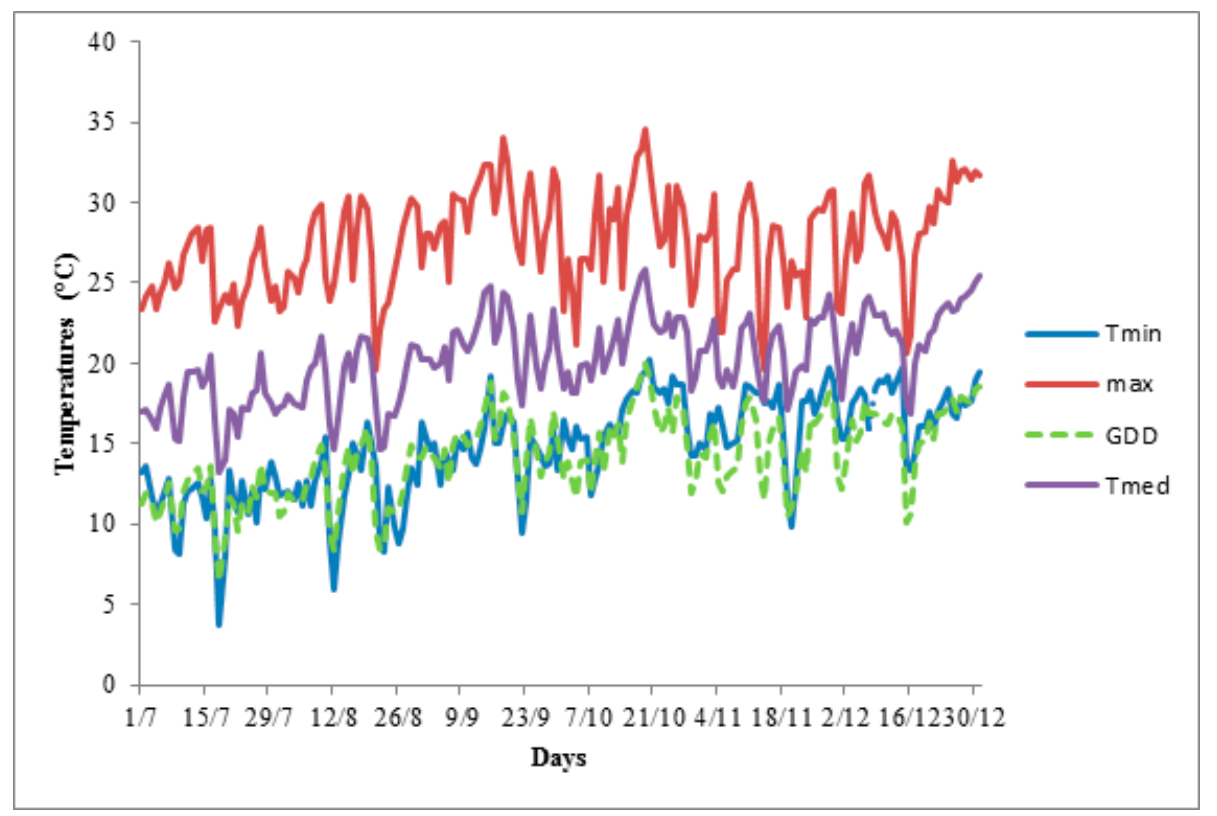

Figure 2. Maximum temperatures (Tmax), minimum temperatures (Tmin), mean temperatures (Tmed), and growing degree-days (GDD) from July to December 2016, in Lavras, MG, Brazil. Source: Main Weather Station of Lavras-UFLA/INMET.

\subsection{Peach Growth Stages}

The fruit mass, fruit diameter, and endocarp data were analyzed through descriptive statistics, and the results were expressed by the means followed by the respective standard deviations (Figure 3), according to Hammami [26]. 

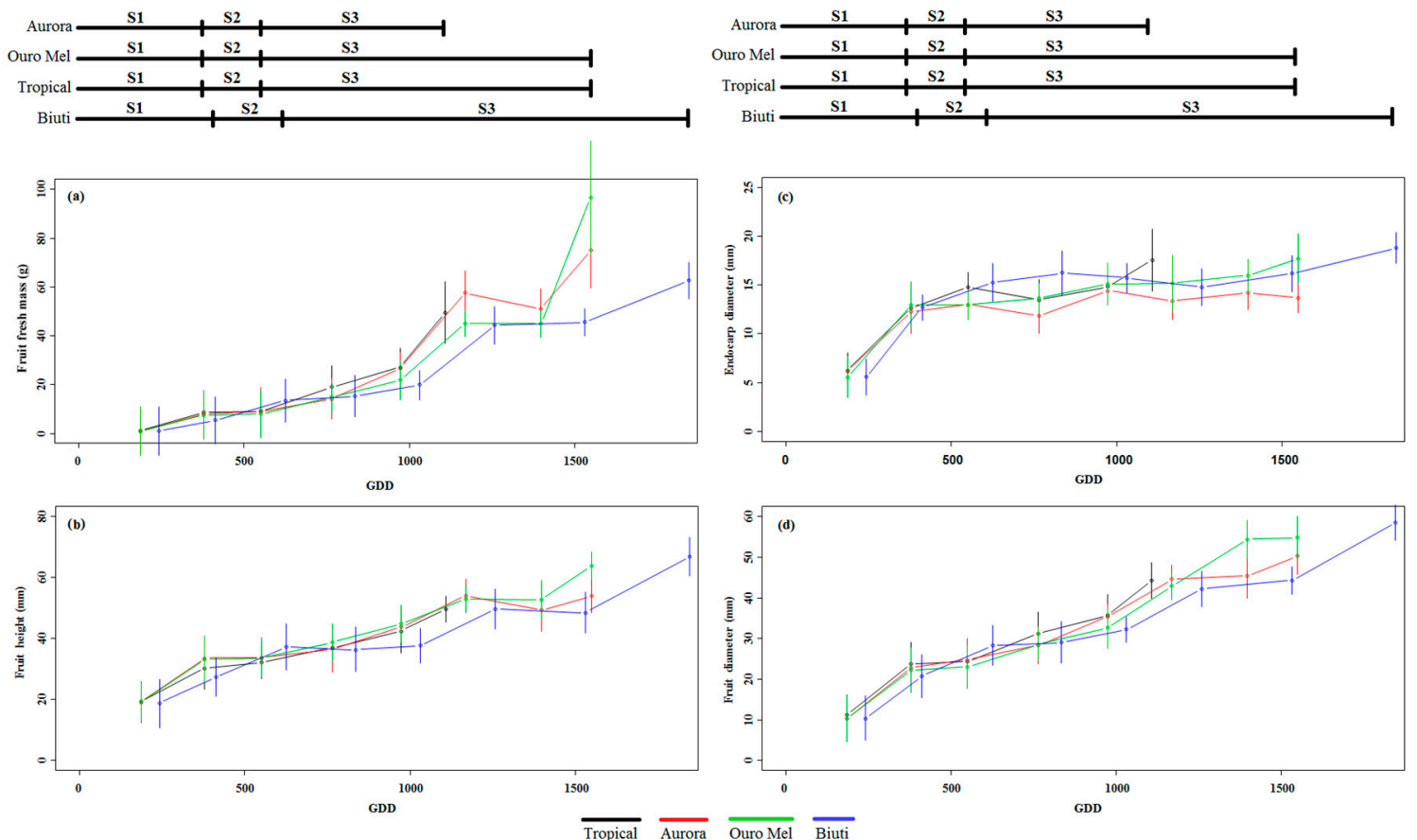

Figure 3. The symbols (S1-S3) above the images represent the peach growth stages. (a) Averages of fruit fresh mass $(\mathrm{g}),(\mathbf{b})$ average fruit diameter $(\mathrm{mm}),(\mathbf{c})$ average endocarp diameter $(\mathrm{mm})$ and $(\mathbf{d})$ average fruit diameter ( $\mathrm{mm}$ ) as a function of growing degree-days (GDD) during peach fruit development (from beginning of flowering to end of harvest) of cultivars grown in a tropical climate region (bars above the averages indicate standard deviations).

The accumulations of fresh mass, and development of the transverse and longitudinal diameter of fruits showed a similar behavior over time and a double-sigmoid growth pattern (Figure 3a,b,d). The growth pattern curve of fruits occurred as observed by Silva [13], with double sigmoid development and three distinct stages: stage I, with exponential growth; stage II, with little growth, and stage III, again with exponential growth culminating with the fruit ripening.

The first phase, known as S1, is characterized by the rapid growth of fruits, mainly due to cell multiplication. Cultivars showed a rapid accumulation of biomass (fresh mass, fruit diameters, and endocarps) (Figure 3a-d) and the GDD of all cultivars were similar in this period, being that 'Tropical' accumulated lower heat, with 346.05 GDD, followed by 'Aurora-2' and 'Ouro Mel-4' (378.50 GDD), and 'Biuti' (411.35 GDD).

The second phase (S2) was characterized by low fresh mass accumulation and low endocarp diameter expansion (Figure 3a,b,d). Tukey [27] describes S2 by the low pericarp growth and rapid embryonic development. The accumulation of degree-days showed in this phase by 'Tropical' was 517.40 GDD, followed by 'Aurora-2' and 'Ouro Mel-4' (549.85 GDD), and 'Biuti' (624.90 GDD). The low biomass accumulation of the fruit was related to the hardening of the endocarp with consequent end of growth, similar to the behavior described by Hammami [26] for olive, which showed an exponential growth after full bloom and subsequent endocarp hardening. Similar results were obtained by DeJong and Goudriaan [17] who studied the influence of temperature on the development of peach fruits and observed that the June Lady variety, with a cycle of approximately 100 days, showed a short Stage II. Dela Bruna [15] studied the growth of peach fruits cultivated in subtropical regions and observed that the growth curve for the early varieties did not show stage II of growth, presenting an accelerated growth from the flowering to the ripening. On the other hand, [12] mentioned that the duration of stage II was longer insofar as the fruit cycle increased.

Afterwards, the third phase begins, where there is a rapid increase of fresh mass and endocarp expansion (Figure 3a,b,d). According to Silva et al. [16], this period shows rapid cell expansion and 
fruit ripening, while [28] described an exponential growth of the pericarp. The heat requirement for 'Aurora-2' was 1106.90 GDD, followed by 'Tropical' (1514.90 GDD), 'Ouro Mel-4' (1547.35 GDD), and 'Biuti'.

In relation to the endocarp development (Figure 3c), the cultivars showed similar behavior and there was rapid growth in the first phase (S1), with a low increase in the diameter of later phases. Thus, the accumulation of degree-days required for the endocarp development was 346.05 GDD for 'Tropical'; 378.50 GDD for 'Aurora-2' and 'Ouro Mel-4', e 411.35 GDD for 'Biuti'. According to Silva [16], the initial stage shows a high rate of cell multiplication and the fruit goes through a period of rapid growth of pericarp and endocarp. Subsequently, there was lignification of the endocarp, thus interrupting the fruit development. According to Scorza [3], stage II is characterized by the limited pericarp growth and rapid embryo development. This behavior can be observed in Figure 4c, where the cultivars show stabilization of the endocarp development after stage I.

The 'Biuti' cultivar showed higher fruit yield in relation to the other cultivars (Figure 3d). This was due not only to the genetic factors but also to a longer development period at the S1 growth stage (cell division phase) and a relatively low rate in phase S2, which corroborates with Yamaguchi's results [10].

After fitting the logistic model, it was verified by the Shapiro-Wilk test and $p$-value (Table 3 ) that errors related to the cell area $(\mathrm{CA})$ and cell number $(\mathrm{CN})$ of all cultivars showed normal distribution, indicating that the model fitting was adequate.

\subsection{Logistic Model Estimates}

Table 3 shows the estimates ( $\beta 1, \beta 2$ and $\beta 3$ ), the standard deviation (in parenthesis) and the coefficient of determination $\left(\mathrm{R}^{2}\right)$ according to the fitted models, for the cell area (CA) and cell number $(\mathrm{CN})$ during the fruit development of the peach cultivars.

Table 3. Shapiro-Wilk estimation of the residues, $p$-value, parameter estimates ( $\beta 1, \beta 2$ and $\beta 3)$, standard deviation (in parenthesis) and coefficient of determination $\left(R^{2}\right)$, according to the logistic model studied for the cell area $(\mathrm{CA})$ and cell number $(\mathrm{CN})$ of four peach cultivars.

\begin{tabular}{cccccccc}
\hline & Cultivars & Shapiro-Wilk & $p$-Value & $\mathbf{R}^{\mathbf{2}}$ & $\boldsymbol{\beta}_{\mathbf{1}}$ & $\boldsymbol{\beta}_{\mathbf{2}}$ & $\beta_{\mathbf{3}}$ \\
\hline & & & & & $9646.60(2613.84)$ & $724.09(153.28)$ & $194.35(89.41)$ \\
CA & & & & $27,320.07(9680.22)$ & $1430.67(292.84)$ & $408.32(79.94)$ \\
& Aurora-2 & 0.890 & 0.053 & 0.88 & $11,514.7(4189.7)$ & $1270.3(367.4)$ & $470.0(123.0)$ \\
& & & & & $21,227.2(9668.8)$ & $1898.7(532.7)$ & $626.0(120.4)$ \\
\hline & Tropical & 0.946 & 0.082 & 0.98 & $27,320.07(9680.22)$ & $1430.67(292.84)$ & $408.32(79.94)$ \\
& Ouro Mel-4 & 0.909 & 0.224 & 0.95 & $11,514.7(4189.7)$ & $1270.3(367.4)$ & $470.0(123.0)$ \\
& 'Biuti' & 0.911 & 0.057 & 0.98 & $21,227.2(9668.8)$ & $1898.7(532.7)$ & $626.0(120.4)$ \\
\hline CN & Aurora-2 & 0.949 & 0.263 & 0.84 & $170,816.85(8213.44)$ & $155.78(67.80)$ & $285.98(96.13)$ \\
& Tropical & 0.958 & 0.564 & 0.94 & $140,949.08(9435.66)$ & $-170.00(79.19)$ & $476.16(170.78)$ \\
& Ouro Mel-4 & 0.908 & 0.053 & 0.85 & $257,194.4(32,147.4)$ & $335.0(126.8)$ & $467.0(185.5)$ \\
& Biuti & 0.959 & 0.417 & 0.94 & $337,429.6(100,527.9)$ & $1150.4(522.2)$ & $803.0(246.1)$ \\
\hline
\end{tabular}

\subsection{Cell Development}

Figure 4a-c shows the logistic model curves for the cultivars in relation to the CN and GDD accumulation during fruit development. According to Figure $4 \mathrm{a}-\mathrm{c}$, the $\mathrm{CN}$ had a significant increase mainly in the early development stage (S1) of the fruit, followed by the stabilization of CN (S2) and subsequent cell growth (S3). These results corroborate with those by King et al. [29], who found that there was rapid growth due to cell division during stage I of development (early stage). On the other hand, the cultivar Biuti (Figure 4d) showed a constant increase in the $\mathrm{CN}$, probably because the fruit showed diameter growth until the end of the development. 

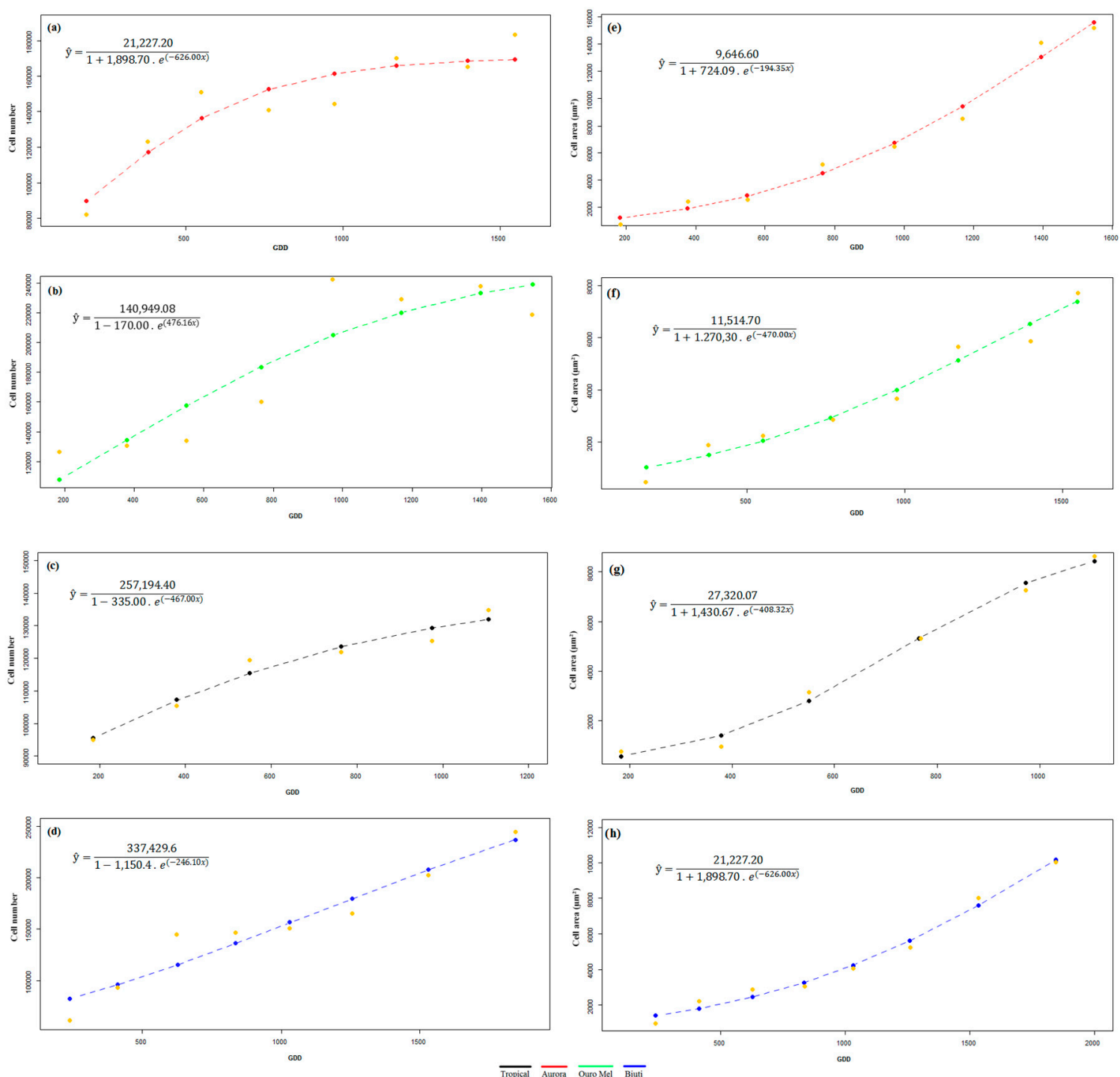

Figure 4. Growth curves observed and fitted for the cell number $(\mathrm{CN})$ and cell area (CA) of 'Aurora-2' $(\mathbf{a}, \mathbf{e})$, 'Ouro Mel-4' (b,f), 'Tropical' (c,g) and 'Biuti' (d,h), according to the logistic model.

According to the model estimate, the 'Biuti' cultivar had the highest $\mathrm{CN}$ in the mesocarp upon reaching the final fruit size, with 258,356 cells, followed by 'Ouro Mel-4' (218,771), 'Aurora-2' (183,361), and 'Tropical' $(134,888)$. These results were lower than those observed by Scorza [3], who obtained 236,000 cells for the 'Boone' rootstock cultivar, 257,000 cells for 'Bailey' rootstock, 564,000 cells for 'Loring', and 581,000 cells for 'Suncrest'. Final fruit size is directly related to the CN and CA; however, the first has a greater influence on final fruit size. Scorza [3] also reported that the final fruit size is mostly influenced by $\mathrm{CN}$ rather than by cell size. Furthermore, these same authors found evidence that other factors contributed to the difference in the final fruit size, e.g., genotypes with larger fruit size present a longer time in stage I (period of high rates of cell division) and a shorter time in stage II (period of limited cell division). Therefore, future research on genetic improvement programs aimed at obtaining larger fruits should invest in materials with a longer period in stage S1.

The CA analysis (Figure 4e-h) was described by the logistic model in relation to GDD accumulation during fruit development. According to the logistic model graphs, the cultivar 'Tropical' (Figure 4g) showed a sigmoid shape that was much better defined than other cultivars (Figure 4e,g,h) and there was a significant increase of the area in the final phase of fruit development. According to Barbosa [30], the pulp resumes its growth in stage III, increasing cellular volumes and intercellular 
spaces, resulting in the fruit ripening. The cultivar 'Ouro Mel-4' showed the highest average cell area at the final development stage, presenting a cell of size 15,178 $\mu \mathrm{m}^{2}$, followed by 'Biuti' $\left(10,041 \mu \mathrm{m}^{2}\right)$, 'Tropical' $\left(8637 \mu \mathrm{m}^{2}\right)$, and 'Aurora-2' $\left(7722 \mu \mathrm{m}^{2}\right)$. These values were lower than those described by Zanchin [13], who observed a cell surface of $37,500 \mu \mathrm{m}^{2}$ in the cultivar 'Redhaven'. However, this cultivar had a superior diameter in relation to those used in this study. However, these values corroborate Scorza [3], who observed a CA of $7840 \mu^{2}$ for the cultivar 'Bailey', $8720 \mu^{2}$ for 'Loring', $9330 \mu \mathrm{m}^{2}$ for 'Boone', and 10,500 $\mu^{2}$ for 'Suncrest'. Yamaguchi [10] observed that both cell number and cell size influence the final fruit size of native (wild) peaches; however, for commercial cultivars, the cell number contributes even more to the final fruit size, influencing around $60 \%$ of the final fruit size. These same authors report that beyond genetic factors, possible differences in final fruit size are also caused by climatic factors, the amount of carbohydrates available during cell expansion, and ovary size during anthesis.

\section{Conclusions}

The temperature greatly influenced the development of peach fruits and each genotype shows a determined thermal requirement to complete the reproductive cycle. The cultivar 'Tropical' shows the lowest agronomic properties of fruits (size and weight) and requires a lower GDD accumulation during the development stages of the fruits, whereas the cultivar 'Biuti' shows higher thermal requirements and higher agronomic properties. The number of cells has a greater influence on the final fruit size than the cell area. Therefore, future research on genetic improvement programs aimed at obtaining larger fruits should invest in materials with a longer period in stage S1.

Author Contributions: Conceptualization, F.S., E.A., R.P., E.C. and G.R., Writing-Original draft preparation F.S., E.A., R.P., E.C., G.R., A.I.F., N.A.M. and R.P., Writing-Review and Editing, F.S., E.A., R.P., E.C., G.R., A.I.F., N.A.M. and R.P.

Funding: This research was funded by The Conselho Nacional de Desenvolvimento Científico e Tecnológico (CNPq), and the Coordenação de Aperfeiçoamento de Pessoal de Nível Superior (CAPES).

Acknowledgments: Thanks to the Conselho Nacional de Desenvolvimento Científico e Tecnológico (CNPq), and the Coordenação de Aperfeiçoamento de Pessoal de Nível Superior (CAPES) for financial support, and the Laboratory of Electron Microscopy and Ultra-Structural Analysis of the Universidade Federal de Lavras.

Conflicts of Interest: The authors declare no conflict of interest.

\section{References}

1. Shulaev, V.; Korban, S.S.; Sosinski, B.; Abbott, A.G.; Aldwinckle, H.S.; Folta, K.M.; Iezzoni, A.; Main, D.; Arus, P.; Dandekar, A.M.; et al. Multiple models for Rosaceae genomics. Plant Physiol. 2008, 147, 985-1003. [CrossRef] [PubMed]

2. FAO. 2016. Available online: http://www.fao.org/faostat/en/\#data/QC (accessed on 17 January 2018).

3. Scorza, R.; May, L.G.; Purnell, B.; Upchurch, B. Differences in number and area of mesocarp cells between small-and large-fruited peach cultivars. J. Am. Soc. Hortic. Sci. 1991, 116, 861-864.

4. Byers, R.E.; Lyons, C.G., Jr. Peach flower thinning and possible sites of action of desiccating chemicals. J. Am. Soc. Hortic. Sci. 1985, 110, 662-667.

5. Fernandez-Escobar, R.; Martin, R.; Lopez-Rivares, P.; Paz Suarez, M. Girdling as a means of increasing fruit size and earliness in peach and nectarine cultivars. J. Hortic. Sci. 1987, 62, 463-468. [CrossRef]

6. Hasegawa, K.; Nakajima, Y. The effects of KT-30 and GA paste treatment on the growth of peach fruit. Res. Rep. Kochi Univ. Agric. Sci. 1988, 37, 141-151.

7. WestWood, M.N.; Batjer, L.P.; Billingsley, H.D. Cell size, cell number, and fruit density of apples as related to fruit size, position in cluster, and thinning method. Proc. Am. Soc. Hortic. Sci. 1967, 91, 51-62.

8. Bradley, M.V. Mean cell size in the mesocarp of mature peaches of different sizes. Proc. Am. Soc. Hortic. Sci. 1959, 73, 120-124.

9. Coombe, B.G. The development of fleshy fruits. Annu. Rev. Plant Physiol. 1976, 27, 207-228. [CrossRef]

10. Yamaguchi, M.; Haji, T.; Miyake, M.; Yaegaki, H. Varietal differences in cell division and enlargement periods during peach (Prunus persica Batsch) fruit development. J. Jpn. Soc. Hortic. Sci. 2002, 71, 155-163. [CrossRef] 
11. Chalmers, D.J.; van den Ende, B. Productivity of peach trees: Factors affectingdry-weight distribution during tree growth. Ann. Bot. (Lond.) 1975, 39, 423-432. [CrossRef]

12. McGlasson, W.B.; Golding, J.B.; Holford, P. Improving the dessert quality of stone fruit. In Postharvest Technologies for Horticultural Crops; Benkeblia, N., Ed.; Research Signpost: Keralla, India, 2009; Volume 2, pp. 49-92.

13. Zanchin, A.; Bonghi, C.; Casadoro, G.; Ramina, A.; Rascio, N. Cell enlargement and cell separation during peach fruit development. Int. J. Plant Sci. 1994, 155, 49-56. [CrossRef]

14. Cunha Júnior, L.C.; Durigan, M.F.B.; Mattiuz, B.; Martins, R.N.; Durigan, J.F. Caracterização da curva de maturação de pêssegos 'Aurora-1', na região de Jaboticabal-SP. Rev. Bras. Frutic. 2007, 29, 661-665. [CrossRef]

15. Dela Bruna, E. Curva de crescimento de frutos de pêssego em regiões subtropicais. Rev. Bras. Frutic. 2007, 29, 685-689. [CrossRef]

16. Silva, D.F.P.; Silva, J.O.C.E.; Matias, R.G.P.; Ribeiro, M.R.; Bruckner, C.H. Curva de crescimento e padrão respiratorio de frutos de genótipos de pessegueiro em região de clima subtropical. Rev. Bras. Frutic. 2013, 35, 642-649. [CrossRef]

17. DeJong, T.M.; Goudriaan, J. Modeling peach fruit growth and carbohydrate requirements: Reevaluation of the double-sigmoid growth pattern. J. Am. Soc. Hortic. Sci. 1989, 254, 103-108.

18. Souza, F.B.M.; Pio, R.; Tadeu, M.H.; Zambon, C.R.; Reighard, G.L. Boric acid in germination of pollen grains and fruit set of peach cultivars in subtropical region. Rev. Ciênc. Agron. 2017, 48, 496-500. [CrossRef]

19. Souza, F.B.M.; Alvarenga, A.A.; Pio, R.; Gonçalves, E.D.; Patto, L.S. Produção e qualidade dos frutos de cultivares e seleções de pessegueiro na Serra da Mantiqueira. Bragantia 2013, 72, 133-139. [CrossRef]

20. Souza, F.B.M.; Pio, R.; Barbosa, J.P.R.A.D.; Reighard, G.; Tadeu, M.H.; Curi, P.N. Adaptability and stability of reproductive and vegetative phases of peach trees in subtropical climate. Acta Sci. Agron. 2017, 39, 427-435. [CrossRef]

21. McMaster, G.S.; Wilhelm, W.W. Growing degree-days:one equation, two interpretations. Agric. Meteorol. 1997, 87, 291-300. [CrossRef]

22. Reighard, G.L.; Souza, F.B.M.; Pio, R. Peach Cell Number and Size is affected by Crop Load and Cultivar. Acta Hortic. 2017, 1160, 357-359. [CrossRef]

23. Alves, E. Introdução à Microscopia Eletrônica de Varredura e de Transmissão. 2004. Available online: http:/ / www.lce.dema.ufscar.br/cursos/Ementa_Cuso_MET.pdf (accessed on 5 January 2018).

24. Cano-Medrano, R.; Darnell, R.L. Cell number and cell size in parthenocarpic vs. pollinated blueberry (Vaccinium ashei) fruits. Ann. Bot. 1997, 80, 419-425. [CrossRef]

25. $R$ software, version 3.3; R Development Core Team: Vienna, Austria, 2017.

26. Hammami, S.B.; Manrique, T.; Rapoport, H.F. Cultivar-based fruit size in olive depends on different tissue and cellular processes throughout growth. Sci. Hortic. 2011, 130, 445-451. [CrossRef]

27. Tukey, H.B. Growth of the peach embryo in relation growth of fruit and season of ripening. Proc. Am. Soc. Hortic. Sci. 1933, 30, 209-218.

28. McGarry, R.; Ozga, J.A.; Reinecke, D.M. Differences in fruit development among large- and small-fruited cultivars of saskatoon (Amelanchier alnifolia Nutt.). J. Am. Soc. Hortic. Sci. 2001, 126, 381-385.

29. King, G.A.; Henderson, K.G.; Lill, R.E. Growth and anatomical and ultrastructural studies of nectarine fruit wall development. Bot. Gaz. 1987, 148, 443-455. [CrossRef]

30. Barbosa, W.; Campo Dall'orto, F.A.; Ojima, M.; Sampaio, V.R.; Bandel, G. Ecofisiologia do Desenvolvimento Vegetativo e Reprodutivo do Pessegueiro em Região Subtropical; Instituto Agronômico: Campinas, Brazil, 1990; p. 37.

(C) 2019 by the authors. Licensee MDPI, Basel, Switzerland. This article is an open access article distributed under the terms and conditions of the Creative Commons Attribution (CC BY) license (http://creativecommons.org/licenses/by/4.0/). 